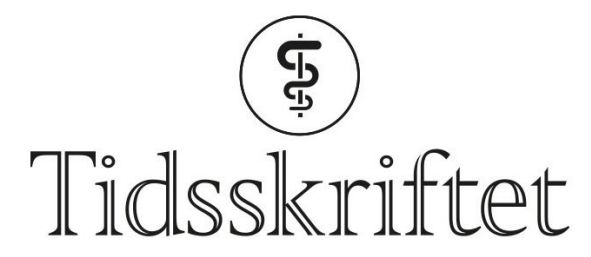

DEN NORSKE LEGEFORENING

\title{
På lag med fremtiden
}

INTERVJU

CHRISTINA SVANSTRØM

E-post: christina@svanstrom.no

Dr. Sverre Håkon Evju i Narvik omtaler seg som kronisk positiv. Med den innstillingen har han blitt en viktig pådriver for endring og utvikling mot fremtidens Helse-Norge.

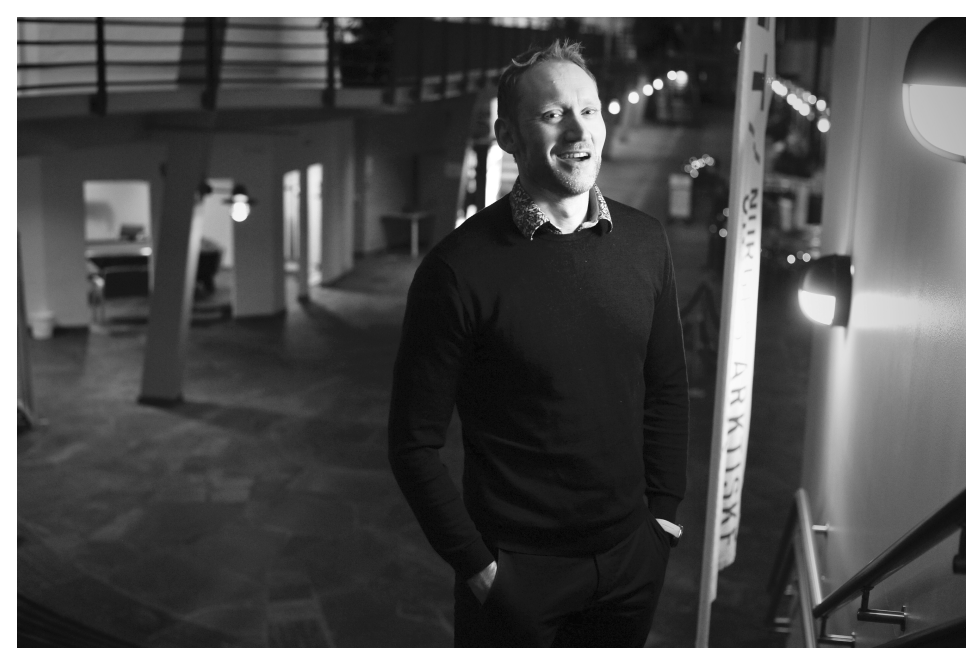

Alle foto: Christina Svanstrøm

- Ja, hvorfor vil dere intervjue meg? Jeg blir litt undrende til sånt, starter Evju ut.

Han kommer rett fra nattevakt, med litt sparsommelig nattesøvn. Vi sitter på kontoret på legevakten i Narvik. Det banker på døren, og en av sykepleierne fra akuttmottaket rett borti gangen kommer inn med en kaffekanne og to små kakestykker.

- Vi sku' bære komme med litt forsyninge her. Skal dokker ha litt mer kaffe?

- Det var nå veldig snilt, hallo, ser du for noen fantastiske kolleger jeg har her?

- Jammen, vi e jo heldig som har han Sverre Håkon, så det e det som e greia her, sier hun, og smiler på vei ut døren.

\section{En arbeidsdag i endring}

Sverre Håkon Evju vokste opp med en mor som var sykepleier, og en far som arbeidet nær fulltid som dyrlege. I mangel på barnehageplass ble unge Evju en tid plassert i pappas dyrlegebil og fraktet med på oppdrag for folk og fe. I ettertid er arbeidsmoral og høflighet noe av det viktigste han har med seg hjemmefra.

Da tiden kom for utdanningsvalg, var det et retningsvalg inn i dyrenes eller menneskenes 
verden. Etter lengre tids interne runder med seg selv, landet han på at mennesker var hans vei å gå. Slik ble det medisinstudiet. Etter den nødvendige turnusregla, tok han noen lange steg i retning kardiologi.

- Men da tiden var inne for siste del av spesialiseringen, fikk vi vår førstefødte. Og det ble for meg uaktuelt å skulle bedrive hasardiøs pendling mellom Narvik og Tromsø.

En kommunal fastlønnsstilling var tilgjengelig på Ankenes. Der har Evju vært siden og har ikke angret ett sekund. Likevel har ikke virkeligheten vært til å unngå.

\section{Sverre Håkon Evju}

Født 1971

Gift, 2 barn

Psykologi grunnfag, Universitetet i Troms $\emptyset$ 1990-91

Medisinsk embetsstudium, Universitetet i Tromsø 1994-2001

Spesialist $\mathrm{i}$ allmennmedisin 2011

Kursansvarlig villmarksmedisin (AWLS), Universitetet i Tromsø 2013-d.d.

Medlem i Sykehusalliansen 2015-d.d.

Styremedlem Universitetssykehuset Nord-Norge 2018-d.d.

Styremedlem i Norsk Legevaktforum 2015-d.d.

- Det er klart jeg har merket at hverdagen for fastlegen har endret seg. Det er mindre og mindre pasientkontakt og stadig flere administrative oppgaver. Fortsetter det sånn, risikerer vi å bli en fastlegebyråkrat, ikke en fastlege for pasientene.

I dag jobber han $50 \%$ på Ankenes og har takket ja til halv stilling som kommuneoverlege i Narvik.

- Faren med 5o/5o er at det fort blir 8o/8o. Men vi får se.

Tilbudene har vært der, om å bevege seg helt vekk fra klinisk praksis og inn i mer administrative arbeidsforhold. For Evju handler det til stadighet om veivalg. Han gir ikke slipp på klinikken så lett.

- Jeg vet fra tidligere når jeg har vært borte fra det kliniske og hatt mer administrative oppgaver, at det er veldig krevende å komme tilbake. Det er ferskvare. Så jeg prøver nok en gang en balansekunst.

\section{Inkluderende makt}

Med unntak av noen studieår har han hele tiden holdt seg i hjemtraktene. Det er ikke mangel på ambisjoner det er snakk om. Evju er full av blomstrende ideer for Helse-Norges fremtid, et engasjement alle som møter ham får ta del i.

- De som skal lage nye rutiner eller nye utforminger mener det utvilsomt godt, men de er langt fra der faget utøves. For meg er det viktig å være til stede der det kliniske foregår dersom jeg skal kunne påvirke planarbeidet.

For Sverre Håkon Evju er det avgjørende at endringene i Helse-Norge kommer innenfra.

- Vi kan ikke holde fast i at ting skal være som før og bli forbanna for at de ikke er det. Men de endringene det er behov for, får mye større gjennomslagskraft hvis alle er med på det. Det handler ikke bare om å inkludere, men å lytte fra starten av, sier Evju.

Han kaller det for Including Power, men tar seg i det:

- På godt norsk må de som skal være med på endringene inkluderes og være med fra starten av. Det funker ikke å komme med pålegg. Å gjøre det sammen har større virkning enn å si «skal» og «må». Endringene må komme fra bunnen og opp. Den typen inkludering har det vært et ganske stort fravær av. 


\section{De enkle løsningene}

Mange kjenner Evju best fra engasjementet for nettopp det prehospitale. Som han selv sier, er det viktig å ha begge føttene på jorden.

- Får du ikke gjort noe med A-en, hjelper det ikke å ha PET-skan på sykehuset. Det er det som har vært mitt engasjement både med akuttmedisinkursene og med villmarksmedisin. Det aller viktigste er det første tiltaket som gjøres.

Det handler om å se muligheter, ikke begrensninger.

Tilfeldighetene ville det slik at en amerikansk kollega som hadde havnet i Narvik introduserte den nokså nyutdannede Evju for Advanced wilderness life support (AWLS). Etter å ha blitt lokket med over Atlanteren på en konferanse om temaet, var doktoren fra Narvik solgt. Det siste drøye tiåret har 11 kurs i Villmarksmedisin vært holdt i røff natur utenfor Narvik.

- Kurset kan være et påfyll til allerede dyktige helsearbeidere. Det er akuttmedisin «utenfor boksen». Vi jobber med å improvisere og stole på egne ferdigheter i utfordrende situasjoner med lite ressurser, sier Evju.

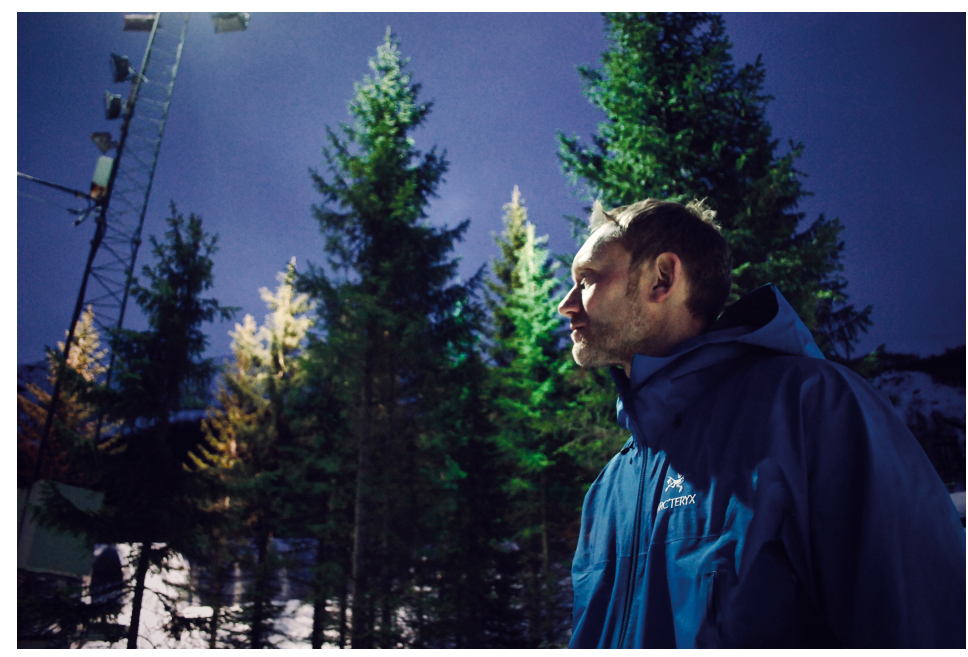

- Vi er verken anestesileger eller eksperter på noen måte. Men vi driller på de enkle tingene. Da blir det enklere å gjøre valg når du senere står i virkelige situasjoner. Make it simple, make it work! Æ e en enkel mann.

\section{Smartere ressursbruk}

Vi forlater legevakten og tar en rundtur i Narvik. Furumoen, tomten til det nye sykehuset (UNN Narvik), står åpen og klar. Tunnelgjennomslaget er gjort, den som skal føre blålysene gjennom berget fra E1o, Hålogalandsbrua, og rett til akuttmottaket.

Godt oppi fjellsiden og med dagslyset på vår side er det rom for vidstrakte tanker. Ennå ligger tomten brakk, men anleggsmaskinene, brakkene og det påfallende tunellhullet i fjellet vitner om at endring er på vei.

- Jeg prøver å løfte blikket litt og se en større sammenheng. Det er en utfordring at helseøkonomien er bygd opp i ulike siloer. Vi klarer ikke få dratt ut hele potensialet når alle verner om egne budsjetter. Det investeres mangfoldige milliarder i nye sykehusbygg. Hvordan skal vi klare å tilpasse oss og møte de utfordringene som kommer de neste tiårene? Vi må i hvert fall samarbeide på tvers av siloene.

Ingen kan spå inn i fremtiden. Men Evju har stått i stormen før og forsøkt å stille spørsmål. Da den nye sykehusplanen kom i 2015, var det sykehusalliansens oppgave å stille spørsmål, prøve å få alle kortene på bordet. Den gang var det store spørsmålet om et akuttsykehus kunne være et akuttsykehus uten akuttkirurgi. Debatten raste.

Evju ble for mange i Nordland kjent i den perioden for sitt engasjement i sykehusalliansen. Han ble kåret Årets nordlending 2015 etter å ha stått i spissen for det han understreker ikke var 
et sololøp.

- Vi var heller ikke en aksjonistgruppe, men vi ønsket å få fakta på bordet. Vi skrev helt bevisst «Blør vi saktere?» med spørsmålstegn, ikke utropstegn.

I dag, noen år etter den forrige nasjonale sykehusplanen, opplever Evju at vinden har snudd. Generellkirurgi kan se ut til å overleve. Lokalsykehusenes funksjon ser ut til å bli anerkjent som en viktig ressurs, og ikke en lurvete utgiftspost.

- Tonen overfor mindre sykehus har endret seg. Større miljøer sitter på spesialiserte funksjoner, og nå ser flere ut til å verdsette den avlastende funksjonen lokalsykehusene har.

Debatten rundt forrige sykehusplan har lagt seg. Nå er det nye temaer som diskuteres. Men Evju har prosessen fra forrige omgang fortsatt friskt i minne.

- At Marit Hermansen og styret i Legeforeningen den gang tok seg tid til å komme opp hit til Nord-Norge og lytte, var avgjørende. Måten de gikk til kildene i distriktet for å inkludere oss, var så viktig. Jeg føler en evig kjærlighet til foreningen etter det, sier Evju.

\section{Ingen rører fjellet}

Vi kjører noen høydemeter til opp i fjellsiden. Her er ny vei, anleggsvirksomhet, nye hus. Narvikfjellet og Narvik fikk i 2018 status som lokalitet for Norges søknad om alpint-VM i 2027. Her er det allerede tydelig smurt tjukt med kløkt og kapital oppetter berget.

Det bygges ny gondolbane. Hyttefelt utvikles, butikk og kafé, skiutleie og hva-enn-du-kantenke-deg er i ferd med å komme på plass.

Ikke uventet har Evju hatt en finger med i spillet også her. Da søknaden skulle ha et helsekapittel, kom kompetansen godt med.

- Nok en gang har det vært utrolig å se hvor mange dyktige folk som stiller opp og vil få til noe.

Narvik er for de fleste kjent som utskipshavn for malm fraktet fra gruver i Nord-Sverige. Det er fortsatt toneangivende for byen.

Ellers har Narviks næringsliv fått kjenne på det siste tiårets svingninger i verdensmarkedet.

Mange arbeidsplasser forsvant da Hurtigruta etter 100 år i Narvik valgte å flytte hovedkvarteret til Tromsø for å spare på kostnadene. Flere hundre arbeidsplasser forsvant i 2012 da solcelleeventyret til REC bukket under i finanskrisen.

- Vi har måttet tenke nytt om hva vi har å by på. For hva er det de ikke kan ta fra oss? Narvikfjellet. De investeringene som gjøres her er virkelige investeringer for fremtiden.

\section{Smart samhandling}

Dagens brennhete sak er at ordningen med et felles akuttmedisinsk mottak, FAM, tas med over i det nye sykehuset. Samlokalisert legevakt og akuttmottak er på sin plass i en by som Narvik, mener Evju.

- Avstand betyr noe, og på et felles mottak får vi raskt tak i dyktige og erfarne medarbeidere. Mange sykehus har gått vekk fra denne løsningen, men i en by som vår er det et viktig sentrum for kompetansedeling og effektiv ressursbruk. 


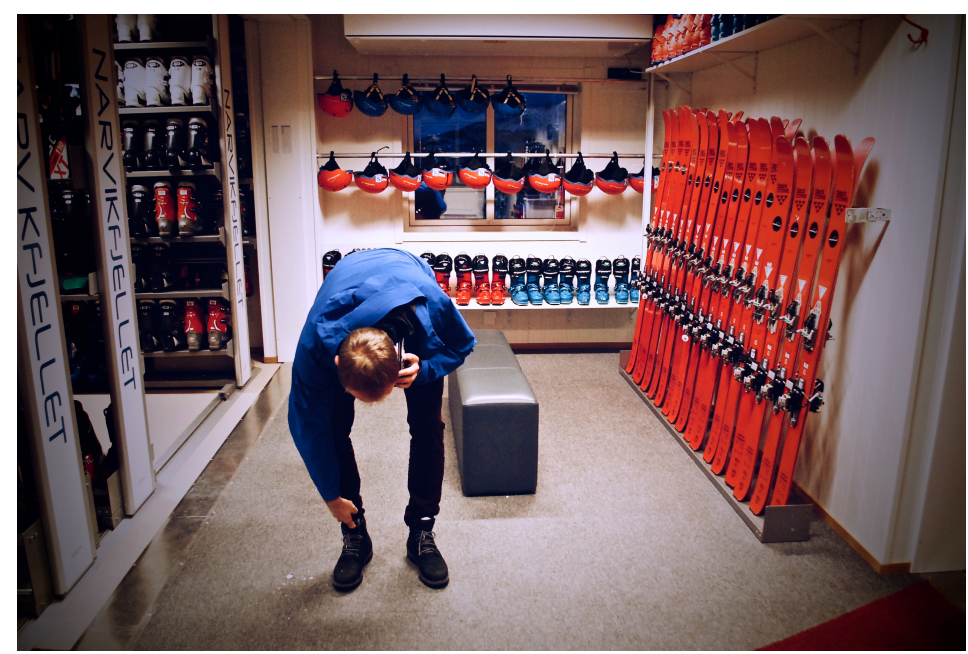

I høst stod Evju i bresjen for en nasjonal helsekonferanse i Narvik, med navnet Fremtidens (smart-) helsetjeneste. Målet var å vise at man i Narvik tør å tenke annerledes.

- Samhandlingsreformen er én ting, men nå må vi få det til. Make it happen.

Det handler om smart teknologi og smart samhandling. Ideene er mange. Evju har visjoner om at Narvik kan bli arenaen for å eksperimentere med fremtidens helseløsninger.

-SUBSS, sier Evju, og blunker med øyet.

- Altså: et Simulerings-, Utviklings- og BeredskapssamtreningsSenter. På Universitetet i Tromsøs avdeling Narvik ligger det et uforløst potensial i teknologiutdanningene, som med sin kunnskap vil kunne stå for drift og utvikling. Kobler man dette sammen med helse, brann, politi og helseutdanninger sitt behov for øvingslokaler, blir mulighetene mange.

For Evju er det enkelt. Det handler om å bedre samhandling på skadested. Det handler om at alle nødetatene kjenner til de samme algoritmene, og det handler om å redde liv.

- Det handler om å ha en arena for å trene, vedlikeholde og utvikle kunnskap, også digitalt. For helsearbeidere i kommune, distrikt og spesialisthelsetjeneste - alle sammen.

- Når politi- og brannvesen er samkjørt med de algoritmene helsevesenet bruker, så vil det $\emptyset$ ke sannsynligheten for bedre behandling av pasienten på skadestedet. Det koker ned til funksjonalitet og bruk av ressurser. Men jeg tror det vil gå seg til, der er jeg kronisk fremoverlent og positiv.

\section{Håndfast avkobling}

Vi kjører ned mot Narvik sentrum. I løpet av et par svinger har Evju løst litt familielogistikk på telefonen, vist frem universitetets lokaler og pekt på utsikten her fra høyden. Han er effektiv som få, men også klar over at et utrettelig engasjement kan bli hans bane om han ikke er på vakt.

Det går litt i bølger, men noen ganger må han bare trekke ut pluggen. Koble fra. Trene. Være med familien, som er hans personlige «dockingstasjon». Han liker å reise til familiehuset på Tjeldøya, hytta uten strøm og vann på fjellet, eller svigerfamilien i Gudbrandsdalen.

- Å måke, skyve stein, arbeide med noe fysisk, det gjør meg godt. En fin og håndfast avkobling fra fastlegekontorets milligram og mikroenheter på medikament og helse. Det er godt å bare få se ting gjort.

Publisert: 22. mars 2019. Tidsskr Nor Legeforen. DOI: 10.4045/tidsskr.19.0o8o

(C) Tidsskrift for Den norske legeforening 2020. Lastet ned fra tidsskriftet.no 